\title{
The Shipmans of East Hawai'i
}




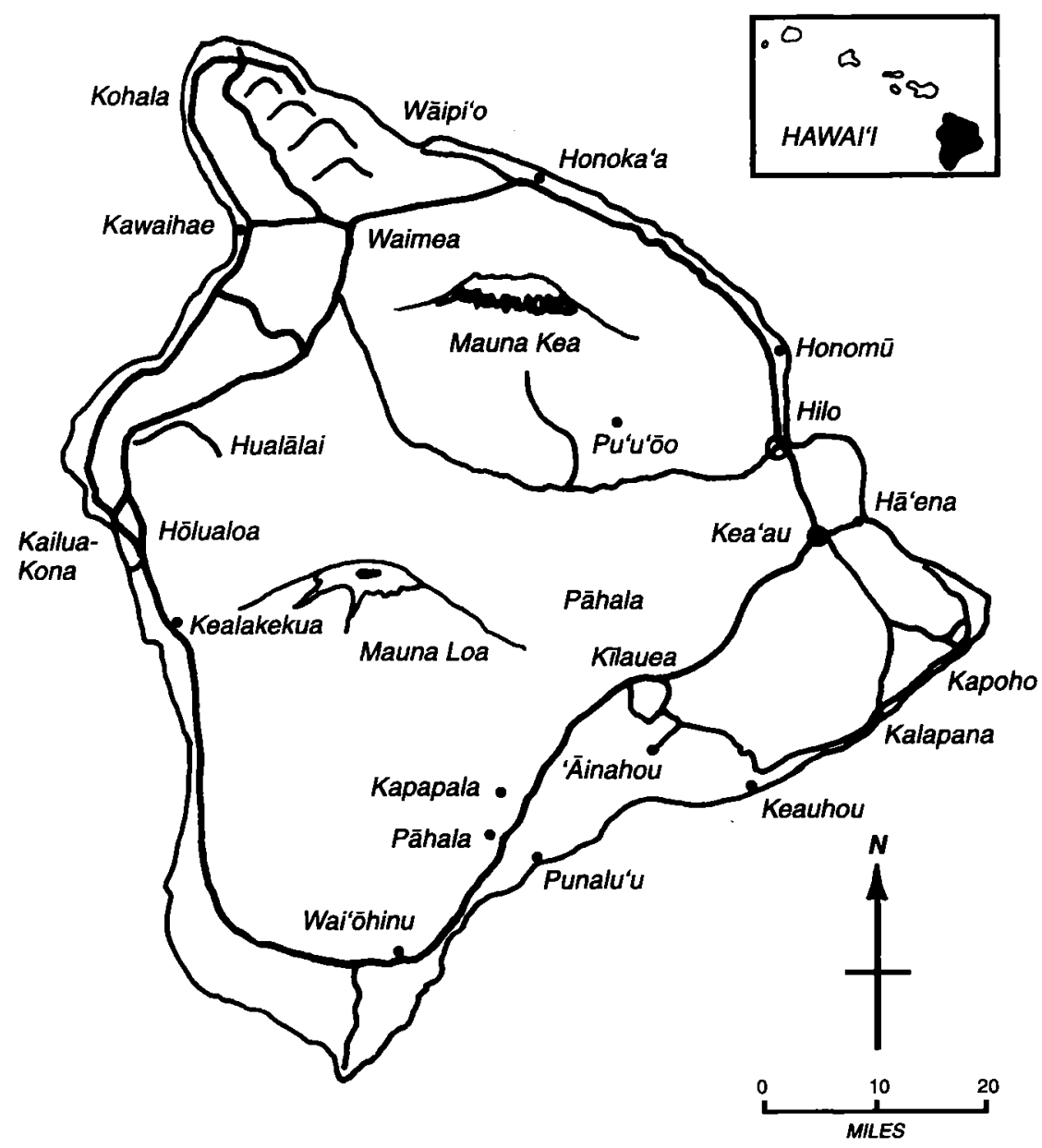

The island of Hawai' $i$ 


\section{The Shipmans \\ of East Hawai' $i$}

EMMETT CAHILL

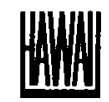

University of Hawai'i Press

Honolulu 
(C) 1996 University of Hawai'i Press

All rights reserved

Printed in the United States of America

$9697989900 \quad 543321$

\section{Library of Congress Cataloging-in-Publication Data}

Cahill, Emmett.

The Shipmans of East Hawai'i / Emmett Cahill.

p. $\mathrm{cm}$.

Includes bibliographical references and index.

ISBN 0-8248-1680-3 (paper : alk. paper)

1. Shipman family. 2. Hawaii-Genealogy. 1. Title.

CS71.\$55675 1996

929'.2'0973—dc20

95-47621

CIP

University of Hawai'i Press books are printed on acid-free paper and meet the guidelines for permanence and durability of the Council on Library Resources

Frontispiece map: The island of Hawai' $i$

Book design by Paula Newcomb 